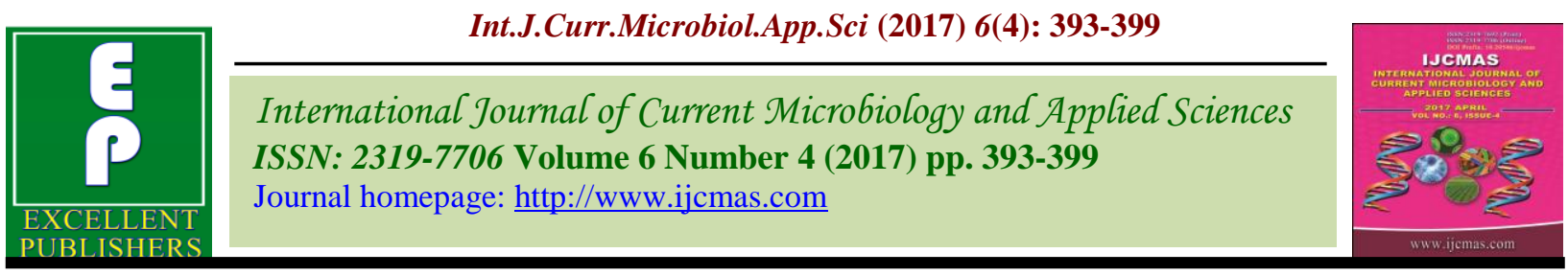

Original Research Article https://doi.org/10.20546/ijcmas.2017.604.044

\title{
Novel Report of Banded Chlorosis in Commercial Sugarcane Cultivars from Sub-Tropical India
}

\author{
Sujeet P. Singh ${ }^{1}$, S.K. Vishwakarma ${ }^{1}$, S.P. Singh ${ }^{1}$, A. Singh ${ }^{1}$ and B.L. Sharma ${ }^{2}$ \\ ${ }^{1}$ Plant Pathology Division, Sugarcane Research Institute (UP Council of Sugarcane Research), \\ Shahjahanpur-242 001, India \\ ${ }^{2}$ UP Council of Sugarcane Research, Shahjahanpur, India \\ *Corresponding author
}

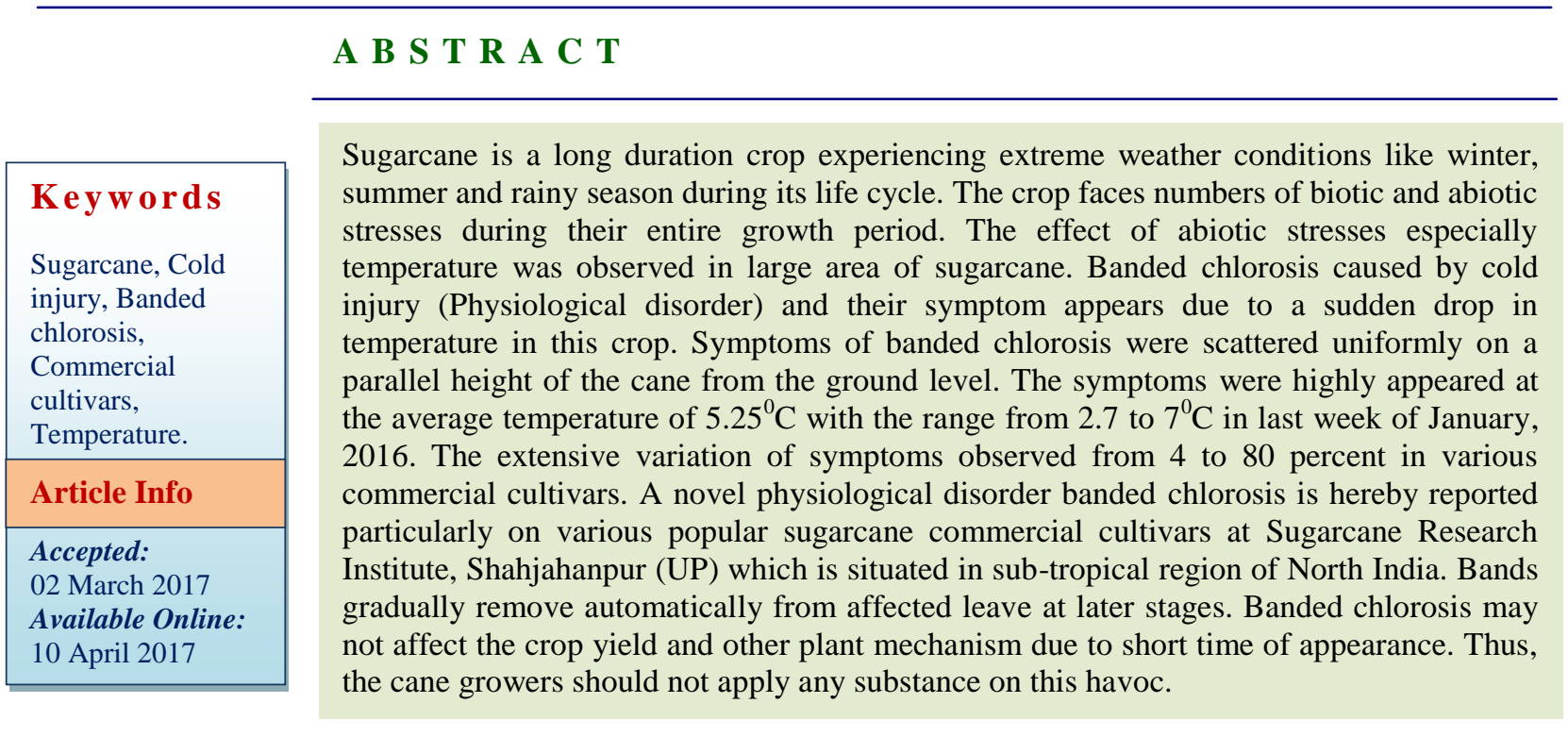

\section{Introduction}

Sugarcane is a long durational crop, which experiencing extreme weather conditions throughout its life cycle in sub tropical part of India. There are various biotic and abiotic stresses faced by this crop during their growth period and maturity. Many diseases caused by fungi, bacteria, viruses and phytoplasmas as well as environmental and physiological stresses cause immense quantity and quality loss of this crop worldwide. Sugarcane yield losses are reported with wide range having 30 to 100 percent throughout India (Vishwanathan and Rao, 2011).
The climate change will lead to more extreme events for rainfall patterns and change in temperature patterns (Nelson et al., 2010). The changes in temperature, rainfall and solar emission patterns affect the productivity and sugar content of sugarcane in both up and down stream. Tremendous change in environmental temperature (low or high) effects to physiological mechanism in sugarcane. The symptom of any stresses firstly appears on leave. The temperature increase than the normal due to climate change is likely to improve cane growth 
during winter since very low temperatures constrain leaf growth rate and photosynthesis and sucrose accumulation (Gawander, 2007). The effect is more pronounced on sugarcane crop when there is sudden drop in temperature rather than decreasing temperature over a period. The severity of the damage varies with the degree of coldness, the variety of cane and the vigour of the plant (Martin et al., 1964). The high temperature chlorotic effect in cane has been noticed in glass house during hot period at Beltsville, Sydney and New South Wales, Australia (Martin et al., 1964).

The chlorotic banding symptom of the disorder appears on cane leave due to the low temperature $\left(8-10^{0} \mathrm{C}\right)$ during January, 2016 to March, 2016. These types of symptoms were first observed in Puerto Rico on the leaves of sugarcane variety P.R. 1059 at Central Aguirre. The prominent bands of chlorosis on the sugarcane leaves termed as "cold chlorosis" (Faris, 1926) or "sectional chlorosis" (Newcomb and Lee, 1927) but in general the broadly termed as 'banded chlorosis'. Banded chlorosis occurs on cane leaves due to both high as well as low temperature (Martin et al., 1964). The banded chlorosis or cold chlorosis or cold injury is especially a physiological disorder which appears due to cold temperature. The banded chlorosis symptom first appeared in the research farm of Guneid, Sudan on the cane variety B 47419 during the year of 1999 (Marchelo et al., 1999). Banded chlorosis has been noticed earlier in tropical region of Maharashtra, India during $2^{\text {nd }}$ week of March 2011. During winter season of 2010-11, the minimum temperature ranged from $10^{\circ} \mathrm{C}$ to $12^{0} \mathrm{C}$ in throughout January 2011, which resulted in such abnormality. The most popular tropical commercial cultivars Co 86032 and $\mathrm{CoC} 671$ affected by banded chlorosis (Web report of VSI, Pune). Waraitch and Kanwar (1977) reported firstly in sugarcane clone from North India in the state of Punjab. They observed the symptom of banded chlorosis on a sugarcane clone $\mathrm{S}$ $98 / 70$ due to severity of low temperature (minimum $0.5^{0} \mathrm{C}$ ). None of the other clones or varieties was affected by this symptom in 1977. An outstanding abnormality of banded chlorosis firstly observed on commercial cultivars at Sugarcane Research Institute, Shahjahanpur (UP), belongs to sub-tropical region of India.

\section{Materials and Methods}

The plantings of sugarcane cultivar were carried out in various experimental plots at research farm of Sugarcane Research Institute (SRI), Shahjahanpur (UP), India during 20152016 in autumn season. The geographical distribution of SRI, Shahjahanpur having Longitude: $79^{\circ} 57^{\prime} \mathrm{E}$, latitude $27^{\circ} 54^{\prime} \mathrm{N}$. Plots were indicated as alphabet from ' $A$ ' to ' $\mathrm{K}$ '. The experiment was planned after the appearance of banded chlorosis in various fields, in which different varieties were planted at same time in October, 2015. The symptom was detected on popular varieties in various experimental plots of research farm during the month of January, 2016 to April, 2016. The sugarcane cultivars were planted in various plots having more distance among them. The varieties namely Co 0118, Co 0238, Co 05011, CoS 08272, CoS 08276, CoS 08279, CoSe 08452, UP 05125, CoLk 94184 and CoSe 01434 were taken for observation from different plots (Table 1).

The observations were taken during the month of January, 2016 to April, 2016 on various varieties. Number of chlorotic affected clumps per row was to be counted along with the total number of healthy clumps. Evaluation of the symptom was based on percentage of total infected clumps (Number of affected clumps/total clumps $\times$ 100). The observations were recorded from respective month from January, 2016 to April, 
2016. The meteorological data i.e. temperature, relative humidity $(\mathrm{RH})$ and rain fall were taken by meteorological department at this institute from January, 2016 to April, 2016.

\section{Results and Discussion}

\section{First report from sub-tropical zone}

Banded chlorosis is uncommon and observed as an outstanding abnormality for the first time in the state of Uttar Pradesh, which belongs to sub-tropical region of North India. The disorder banded chlorosis was first noticed on popular sugarcane commercial cultivars in the research farm at Sugarcane Research Institute, Shahjahanpur (UP), India. Three months old sugarcane crops were broadly affected by banded chlorosis. All other ratoon as well as spring planted crops of commercial sugarcane varieties did not show any symptom although they were grown in neighbouring field. The affected popular cultivars were planted in various plots with more distances. The symptoms were scattered uniformly on a parallel height of the cane and, also observed in various patches. During winter season of 2015-16, the minimum temperature ranged from 2.7 to $7^{0} \mathrm{C}$ in throughout January 2016, which resulted in such an abnormality. The chlorotic bands are positioned at the mid portion of the leaves and all the bands progressively closer to the tips.

\section{Symptoms}

The average minimum temperature in the last week of January, 2016 was $5.25^{\circ} \mathrm{C}$ (2.7 to $7^{0} \mathrm{C}$ ) month, at that time the severity of the symptoms somewhat, appeared on the leaves of various varieties. The relative humidity was recorded as 77.14 percent and rain fall was also observed $1.6 \mathrm{~mm}$ at severity time (Last week of January, 2016). The average minimum and maximum temperature were computed as $7.29^{\circ} \mathrm{C}$ and $20.9^{\circ} \mathrm{C}$, during January, 2016 respectively. Mean relative humidity was observed as 76.37 percent in January, 2016. The more effect appears on sugarcane leave of commercial cultivars due to a sudden drop in temperature $\left(5.25^{\circ} \mathrm{C}\right)$ over a period of last week of January, 2016 (Table 2 and Fig. 1). Martin et al (1964) reported that the banded chlorosis or physiological disorder which become appears due to cold temperature. The first reported from North India was elucidated by Waraitch and Kanwar (1977) in Punjab state. They revealed the symptom of banded chlorosis on a sugarcane clone S-98/70 due low temperature $\left(0.5^{0} \mathrm{C}\right)$. The symptom of affected varieties has horizontal area of chlorotic tissue extending across the leaf on the both side of the midrib. The colour varies from dead white or pale yellowish-green or yellowish white. Horizontal chlorotic bands measured approximately 3-7 $\mathrm{cm}$ wide, which extending continuously across the leaf lamina at some intervals. Horizontal chlorotic bands appeared on both side of leaf lamina in same length (Fig. 2-5). Generally, one chlorotic band present on individual leaf but somewhat more than one chlorotic band also occurred in some commercial varieties like $\mathrm{CoS} 08279$ and Co 0228 (Fig. 4). VSI, Pune reported similar report on commercial cultivars viz., Co 86032 and $\mathrm{CoC} 671$ suffered more. The single patch of 2 to 3 inch length was also observed on individual leaf. Drying of whole leaves or stalks was not observed anywhere. But, in a few affected leaves, necrosis and thereby shredding is noticed within the patches/bands. The banded chlorosis symptom observed on various clumps of same variety in a particular field, more or less equally distributed at similar position or same height on leaves of similar age from the ground level in present study. Some study was also revealed that the chlorotic band occurred mostly due to low temperature. Similar findings reported by earlier workers on sugarcane variety P.R. 
1059 (Mendez Roig, 1966) and B 47419 (Martin et al., 1964).

Leaf alteration and other abnormalities were not seen on affected part of leaf blade. The inter-veinal strips in the banded area become brown colour and the affected banded portions collapse or shredding at the later stage of the injury. During later stage tissues are damaged with longitudinally splitting and cracking (Fig. 5). Whole leaves or stalks of the affected variety did not damage at any stage. The chlorotic band may persist unaffected until the death of the leaf through old age. Bands were positioned on middle of the leaf at earlier stage of detection in January, 2016 (Fig. 2) and then progressively remove at later stage in March, 2016 and April, 2016 (Fig. 3). There is considerable variation in varietal resistance to banded chlorosis. Some varieties were found resistant under same climatic conditions, whereas other varieties showed symptom of banded chlorosis.

Table.1 The banded chlorosis symptom observed on various popular sugarcane commercial cultivars in a particular respective field

\begin{tabular}{|c|c|c|c|c|}
\hline $\begin{array}{c}\text { Sl. } \\
\text { No. }\end{array}$ & $\begin{array}{c}\text { Varieties } \\
\text { affected }\end{array}$ & $\begin{array}{c}\text { Symptoms } \\
\text { occurrence (\%) }\end{array}$ & $\begin{array}{c}\text { More than one } \\
\text { band appear } \mathbf{\%})\end{array}$ & Plot Number \\
\hline 1 & Co 0118 & 5 & NA & A \\
\hline 2 & Co 0238 & 20 & NA & B \\
\hline 3 & Co 0238 & 5 & NA & C \\
\hline 4 & Co 0238 & 40 & 2 & D \\
\hline 5 & Co 0238 & 4 & NA & E \\
\hline 6 & Co 05011 & 10 & NA & F \\
\hline 7 & Co 05011 & 4 & NA & G \\
\hline 8 & CoS 08279 & 80 & 10 & H \\
\hline 9 & CoS 08279 & 20 & NA & J \\
\hline 10 & $\operatorname{CoS} 08452$ & 4 & NA & K \\
\hline 11 & CoS 08276 & 4 & R & D \\
\hline 12 & CoS 08272 & R & R & D \\
\hline 13 & UP 05125 & R & R & B \\
\hline 14 & CoLk 94184 & R & R & B \\
\hline 15 & CoSe 01434 & R & & \\
\hline
\end{tabular}

$\mathrm{R}=$ Resistant, $\mathrm{NA}=$ Not appear.

Table.2 Meteorological data of different months

\begin{tabular}{|c|c|c|c|c|c|c|c|c|c|c|}
\hline \multicolumn{6}{|c|}{ January, 2016} & \multirow{3}{*}{ Months } & \multirow{2}{*}{\multicolumn{2}{|c|}{ Temperature }} & \multirow{3}{*}{$\begin{array}{c}\text { RH } \\
\text { Mean }\end{array}$} & \multirow{3}{*}{ Rain } \\
\hline \multirow{2}{*}{ Week } & \multicolumn{2}{|c|}{ Temperature } & \multicolumn{2}{|c|}{ RH } & \multirow{2}{*}{ Rain } & & & & & \\
\hline & Max & Min & Max & Min & & & Max & Min & & \\
\hline I Week & 23.6 & 7.74 & 92.86 & 52.14 & - & December, 2015 & 22.8 & 8.9 & 73.1 & - \\
\hline II Week & 22.83 & 8.96 & 93.29 & 57.57 & - & February, 2016 & 25.9 & 11.7 & 67.1 & - \\
\hline III Week & 17.14 & 7.21 & 92.43 & 73.14 & - & March, 2016 & 31.7 & 16.6 & 57 & $\begin{array}{l}4.4 \\
\mathrm{~mm}\end{array}$ \\
\hline IV Week & 20.05 & 5.25 & 89.43 & 64.86 & $1.6 \mathrm{~mm}$ & April, 2016 & 38.7 & 22.4 & 34.46 & - \\
\hline Mean & 20.9 & 7.29 & 92 & 60.73 & $1.6 \mathrm{~mm}$ & Mean & 29.78 & 14.90 & 57.92 & - \\
\hline
\end{tabular}


Fig.1 Maximum frequency of banded chlorosis in IVth week of January, 2016

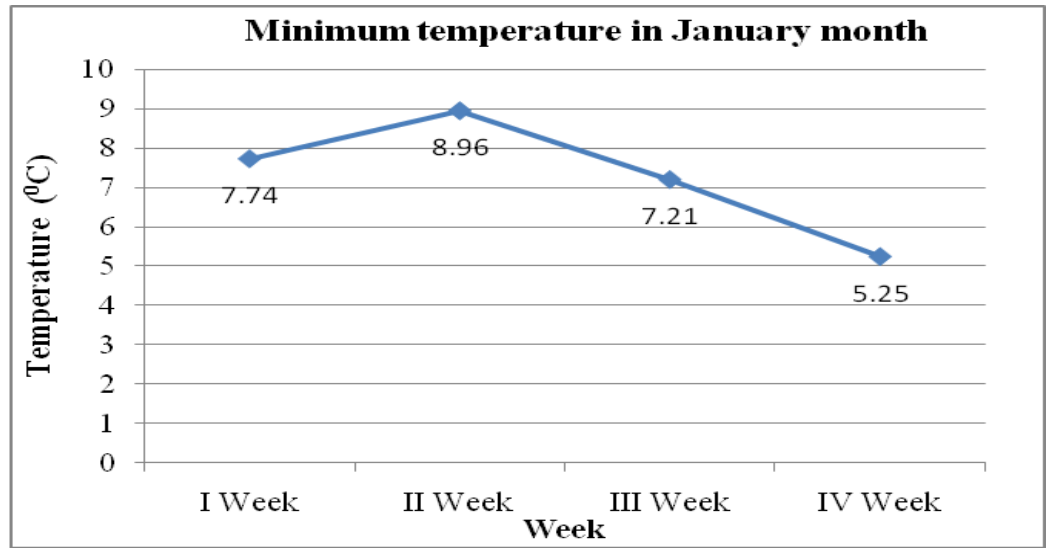

Fig.2 Banded chlorosis symptoms on sugarcane variety Co 0238 at initial stage in the IV week of January, 2016 (A, B)

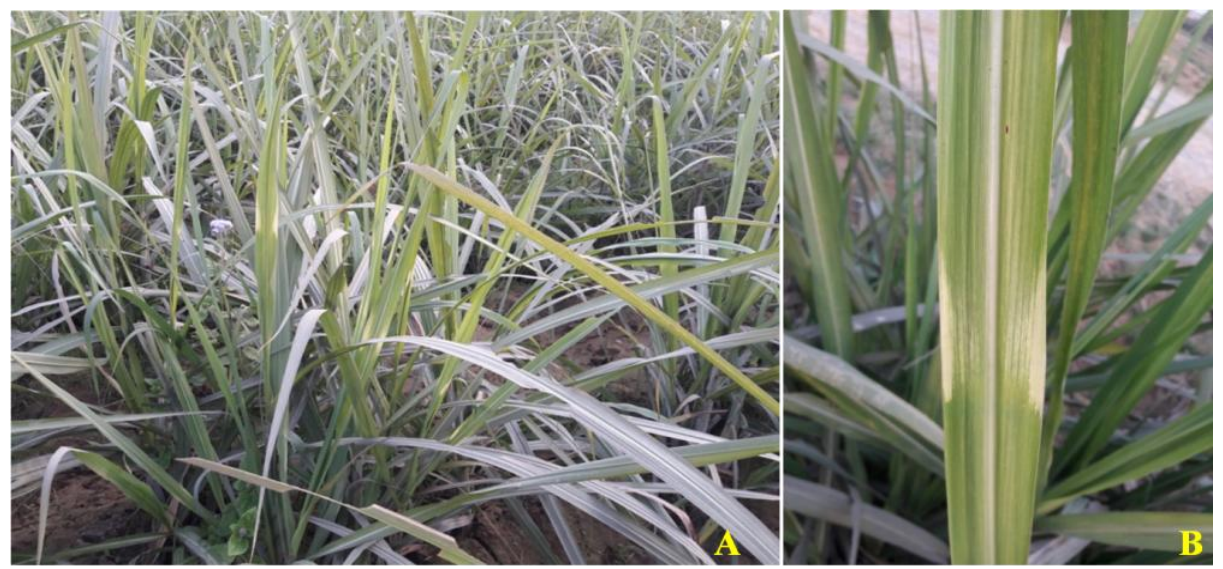

Fig.3 Severity of banded chlorosis on sugarcane variety CoS 08279 at mid stage during February, 2016 and March, 2016 (A, B). Extreme right is at later stage (C)

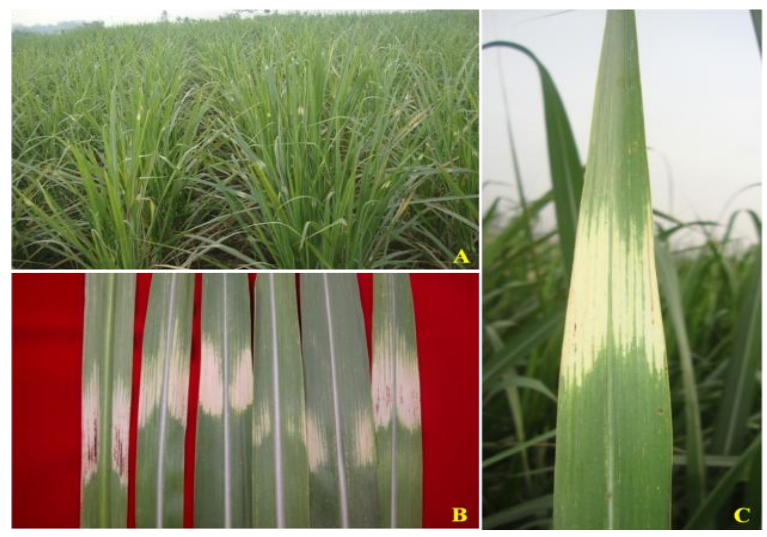


Fig.4 Two uniform bands symptom of banded chlorosis observed on CoS 08279 variety $(\mathrm{A}, \mathrm{B}, \mathrm{C})$

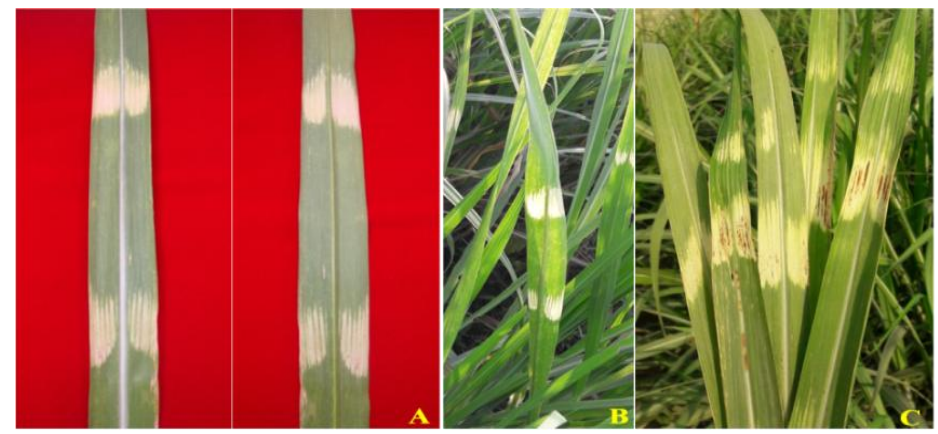

Fig.5 Brown streak observed at later stage (April month) of banded chlorosis symptom on sugarcane variety CoS 08279 (A, B, C) and brown streak observed on both side of leaf lamina (D and E)

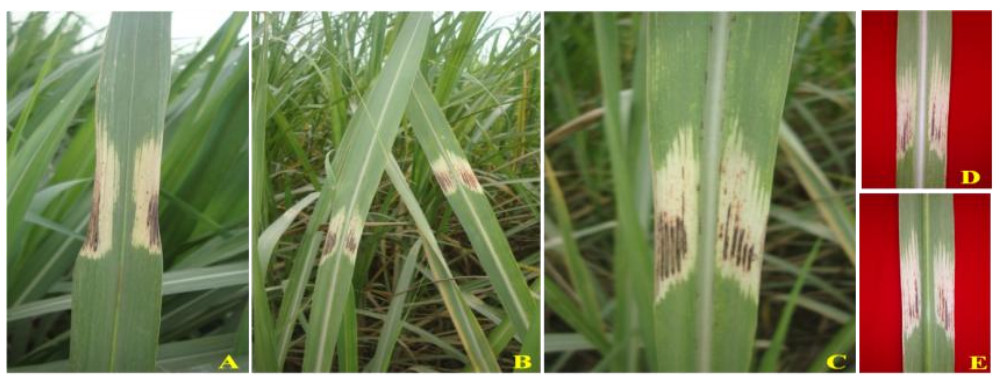

Frequency of banded chlorosis in commercial cultivars

The water stress occurs in the leaf spindle due to low temperature. Banded chlorosis occurs as a result of cold damage to portions of unrolled leaves within the spindle. The damage is visible clearly within the weeks, when the leaves grow out. This damage does not affect the crop yield and other plant mechanism. The autumn planted crops with higher length were more affected by this abnormality. The spring planted crops were shorter in length, were not affected by this injury.

The autumn planted crops with higher length were more affected whereas spring planted crops were shorter in length, were not affected by this injury. The varieties i.e. CoS
08272, UP 05125, CoLk 94184 and CoSe 01434 having the shorted length in particular field was free from the banded chlorotic tissue. A wide variation of this disorder monitored from 4 to 80 percent in various commercial cultivars. Usually, fast growing sugarcane cultivars were more affected by banded chlorosis. The symptoms appeared more on border stalks of the field due to the facing cold wind than the inside stalks. Fast growing mid late maturing cultivars $\mathrm{CoS}$ 08279 facing directly cold wind on their leaves in winter season. The symptoms appeared on variety $\operatorname{CoS} 08279$ and it varied from 20 to 80 percent (Fig. 3). More than one band appeared on this variety with the frequency range of 5 to 10 percent (Fig. 4). The popular early maturing cultivar of north India Co 0238 was adversely affected by this injury, frequency varied from 4 to 40 percent 
from various fields (Fig. 2). Two bands were also appeared on this variety with the frequency of 2 percent. One mid late maturing cultivar Co 05011 was also affected with the range of 4 to 10 percent. One early maturing popular cultivar Co 0118 showed the symptom on their leaves with 5\%. Two another mid maturing cultivars viz., CoSe 08452 and $\operatorname{CoS} 08276$ were also expressed the symptom having the frequency of 4 percent. The symptoms did not appear on the cultivars viz., CoS 08272, UP 05125, CoLk 94184 and CoSe 01434 in the same field, in which affected cultivar Co 0238 was planted (Table 1).

In conclusion temperature was normal cooler in the month of December, $2015\left(8.9^{\circ} \mathrm{C}\right)$ and during first week of January $\left(7.74^{\circ} \mathrm{C}\right)$, but in last week of January, 2016, there was sudden fall in temperature. The symptoms of banded chlorosis were appeared on autumn planted varieties of 3 month age. All the symptoms were disappeared at the end of April, 2016 automatically without any control measure. Hence, total duration of this disorder was covering around 4 month. Economic losses by this injury or disorder were not observed in field area, while all the commercial cultivars during this stage were ready to harvest or at maturing phage. Thus, the cane growers should not apply any substance on this havoc.

\section{Acknowledgments}

Authors are thankful to Dr. M.M. Singh for providing meteorological data, which was more useful to correlate the symptom with temperature, rain fall and relative humidity.

\section{References}

Faris, J.A. 1926. Cold chlorosis of sugarcane. Phytopathol., 16: 885-891.

Gawander, J. 2007. Impact of climate change on sugarcane production in Fiji. WMO Bull., 56: 34-39.

Marchelo P.W., O. Ahmed and Bukhari K.A. 1999. A white leaf banding disorder (WLBD) of sugarcane (Saccharum spp.) in the Sudan. Gezira J. Agri. Sci., 6(2): 262-266.

Martin, J.P., C.A. Wismer and Hughes C.G. 1964. Environmental effects, pp. 239242. In: C.J. Hughes, E.V. Abbott, and C.A. Wismer (eds.). Sugarcane Diseases of the World Vol. (II). Elsevier Publishing Company, Amsterdam, pp. 239-264.

Mendez Roig, F. 1966. Occurrence of banded chlorosis of sugarcane in Puerto Rico. $J$. Agr. Univ. Puerto Rico., 76-81.

Nelson, V., J. Morton, T. Chancellor, P. Burt and Pound P. 2010. Climate change, agricultural adaptation and fair trade, identifying the challenges and opportunities. Natural Resources Institute, University of Greenwich. 1: 145.

Newcomb, F. and Lee. H.A. 1927. The cause of sectional chlorosis of sugarcane. Hawaiian Planters' Record, 31: 125128.

Waraitch, K.S. and Kanwar, R.S. 1977. Banded chlorosis in sugarcane clone S98/70. Sugarcane Pathologists' Newslett, (19): 1-2.

\section{How to cite this article:}

Sujeet P. Singh, S.K. Vishwakarma, S.P. Singh, A. Singh and B.L. Sharma. 2017. Novel Report of Banded Chlorosis in Commercial Sugarcane Cultivars from Sub-Tropical India. Int.J.Curr.Microbiol.App.Sci. 6(4): 393-399. doi: https://doi.org/10.20546/ijcmas.2017.604.044 